\title{
Tectonic rotations in central Chile: New insights on the southern limit of the Maipo Orocline
}

\author{
C. Puigdomenech ${ }^{\text {a, }}$, S. Alarcón ${ }^{\mathrm{b}}$, V. Ruiz González ${ }^{\mathrm{a}}$, P. Rossel ${ }^{\mathrm{b}}$, D. Orts ${ }^{\mathrm{c}, \mathrm{d}}$, C. Zaffarana ${ }^{\mathrm{c}, \mathrm{d}}$ \\ ${ }^{\text {a }}$ IGEBA-CONICET, Argentina \\ ${ }^{\mathrm{b}}$ Universidad Andres Bello, Facultad de Ingeniería, Geología, Autopista Talcahuano, 7100, Concepción, Chile

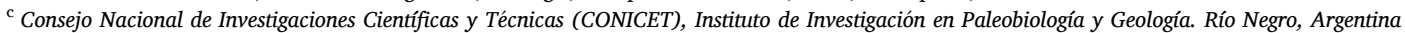 \\ ${ }^{\mathrm{d}}$ Universidad Nacional de Río Negro, Instituto de Investigación en Paleobiología y, Geología, Río Negro, Argentina
}

\section{A R T I C L E I N F O}

\section{Keywords:}

Maipo orocline

Paleomagnetism

Tectonic rotation

Triassic plutons

\begin{abstract}
A B S T R A C T
The Maipo Transition Zone or Maipo Orocline represents a change in strike of the topography from N-S between $30^{\circ}$ and $33^{\circ} \mathrm{S}$ to an NNE-SSW trend to the south. The southern flank of the Maipo Orocline can be traced along strike to around $38^{\circ} \mathrm{S}$. There the Andean margin exposes another orogen bending, the Arauco Orocline. Although the tectonic evolution of this segment of the Andean chain is relatively well constrained, the limit between both oroclines is unclear. In this paper, we show the results of a paleomagnetic study carried out in three plutons of Upper Triassic age located along the Coastal Cordillera of central Chile between $35^{\circ}$ and $37^{\circ} \mathrm{S}$. Paleomagnetic analysis from Constitución Granite and Cobquecura Pluton shows an increase of clockwise vertical-axis rotations from north to south consistent with previous data, whereas results obtained in the Hualpén Stock, located to the south, shows minors counter-clockwise rotations. This change in the rotation pattern would reflect the Maipo and Arauco Oroclines limit. The similar amounts of tectonic rotations recorded by Mesozoic and Miocene rocks indicate that the whole area behaved as a single block and constrains the maximum possible age for the occurrence of tectonic rotations to Miocene.
\end{abstract}

\section{Introduction}

The Andean Cordillera extends for more than $8000 \mathrm{~km}$ on South America's western margin from the Caribbean Sea at its north end to the Scotia Ridge at the south end. Although this mountain range is a continuous element, its geological history involves a complex record of accretions, collisions and two important periods of subduction-related magmatism, the Carboniferous to Permian Gondwana Orogeny (e.g., Mpodozis and Ramos 1989; Bahlburg and Hervé 1997) and the Jurassic to Recent Andean Cycle, with its ongoing subduction along the Andean trench (e.g., Coira et al., 1982; Mpodozis and Ramos 1989). This generates a complicated segmentation where tectonics, magmatism and sedimentation processes change over time and space.

Three large pronounced curvatures of tectonic trends are present along the topographic front of the southern Central Andes, including important changes in the rotations pattern and from north to south these are the Vallenar, Maipo and Arauco oroclines (Arriagada et al. 2009, 2013; Ferrando et al., 2014).

The orocline concept was formulated by Carey (1955) for an orogenic system which has been flexed in plan view to an elbow shape in a subsequent deformation phase. While having a genetic connotation, this term is often incorrectly used in the literature as a geometric description for any orogenic curvature regardless of the actual kinematics of the curvature formation. One of the mechanisms most common involved in the formation of an orocline, proposed by Isacks (1988), is the presences of differential shortening along the belt causing tectonic rotations.

The Maipo Transition Zone (Yáñez et al., 2002) or Maipo Orocline (Farías et al., 2008) represents a change in strike in the topography, geologic units and major structures. The trend of major structures changes from N-S between $30^{\circ}$ and $33^{\circ} \mathrm{S}$ in the north to a NNE-SSW trend to the south. While the northern segment of the curvature corresponds with the ongoing subduction of the Pampean flat-slab segment, which converges nearly horizontally beneath the South American lithosphere, the southern segment coincides with the normal subduction segment developed to the south of $33^{\circ} \mathrm{S}$ (Isacks 1988; Ramos et al., 2002).

Previous paleomagnetic analysis from Jurassic to Late Cretaceous

\footnotetext{
* Corresponding author. Departamento de Ciencias Geológicas, Pabellón 2, Ciudad Universitaria, Buenos Aires, C1428EHA, Argentina.

E-mail address: carlapuigdo@gmail.com (C. Puigdomenech).
} 
rocks in the Chilean-Pampean flat-slab segment shows small to nonsignificant clockwise vertical-axis rotations (Beck et al. 1986, 1990; Creixell et al., 2006). In contrast, towards the south on the normal subduction segment, paleomagnetic results obtained in Late Jurassic to Neogene rocks show systematical clockwise rotations of up to $40^{\circ}$ (Arriagada et al., 2013). The southern flank of the Maipo Orocline can be traced along strike to around $38^{\circ} \mathrm{S}$. There, the Andean margin exposes another orogen bending, the Arauco "Orocline" (Fig. 1; Melnick et al., 2009). However, currently, no detailed paleomagnetic studies confirm the occurrence of tectonic rotations and the limit between both oroclines is still unknown.

In Triassic to Jurassic times, the Chilean active continental margin experienced significant changes in the tectonic and magmatic regimes due to the transition from the Gondwana to the Andean subduction process. In the segment between $34^{\circ}$ and $42^{\circ} \mathrm{S}$, the Late Paleozoic-Early Mesozoic magmatic activity is typical for a magmatic arc experiencing abundant crustal recycling, with the formation of large granitic batholiths and decreasing magma volumes with time toward the Late Triassic (Martin et al., 1999; Lucassen et al., 2004). Early Mesozoic intrusions in the western part of the Cordillera de la Costa comprise, from north to south, La Estrella Granite, Pichilemu Granite, Constitución Granite,
Cobquecura Pluton, and the Hualpén Stock. In this contribution, we report new paleomagnetic data of the Late Triassic Constitución, Cobquecura and Hualpen plutons, which crop out along the Cordillera de la Costa between $33^{\circ}$ and $37^{\circ} \mathrm{S}$. They are post-orogenic intrusions with respect to the Gondwanic orogenic cycle and their study allows us not only to investigate the southern limit of the Maipo Orocline but also to work out the possibility of tectonic rotations related to the Gondwana Breakup.

\section{Geological setting}

During the transit from the Gondwanan to the Andean subduction, the active continental margin experienced significant changes in the tectonic and magmatic regimes. The igneous activity in the Late Paleozoic between $34^{\circ}$ and $42^{\circ} \mathrm{S}$ shows typical features of magmatic arc with abundant crustal recycling, with the formation of large granitic batholiths (Berg and Breitkreuz 1983; Berg et al., 1983), that intrude previously metamorphosed sedimentary units, leading to the formation of the Late Paleozoic Paired Metamorphic belt of Central and Southern Chile (Aguirre et al., 1972; Hervé et al., 1988).

The units that form this paired metamorphic complex are subdivided

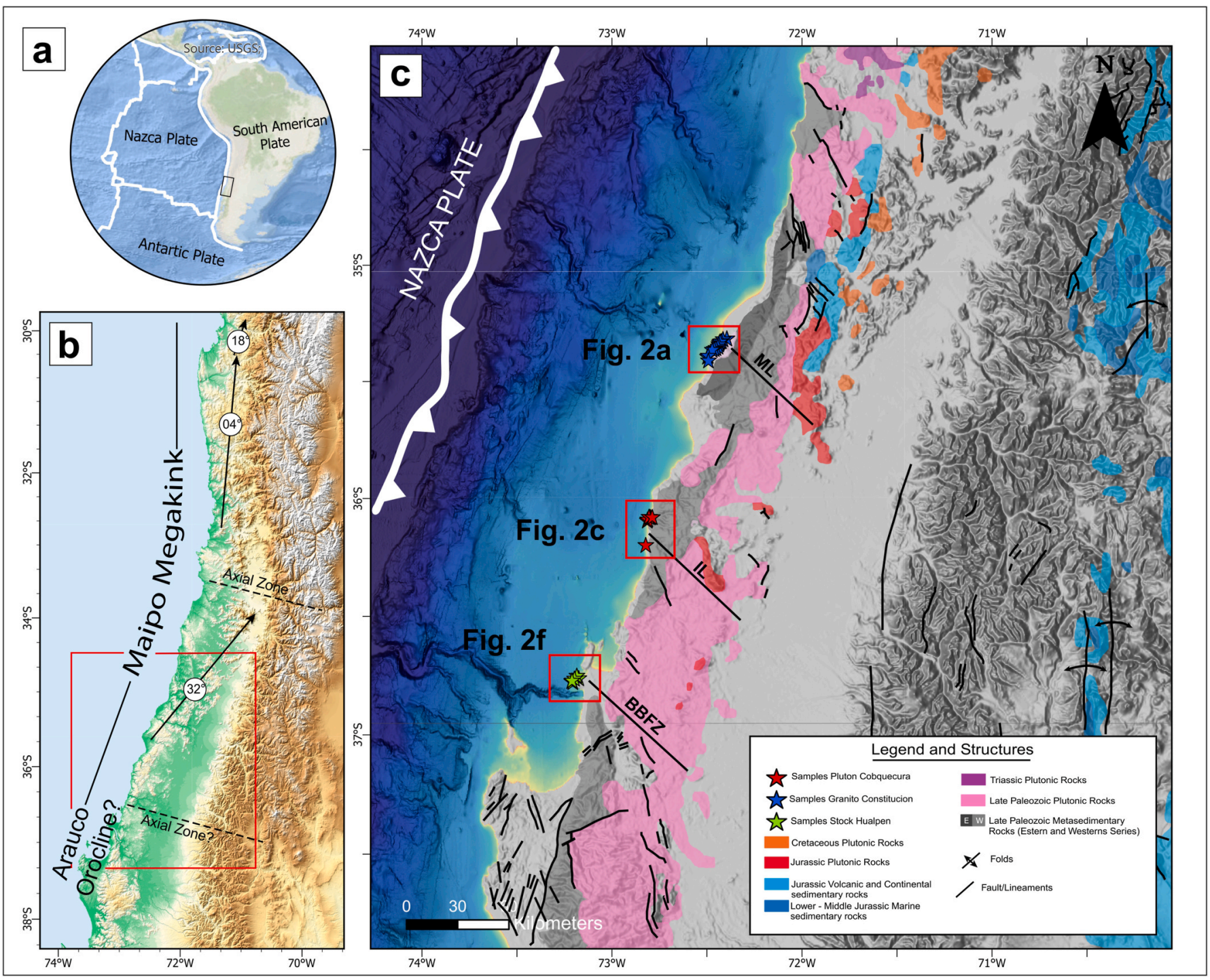

Fig. 1. (a) Tectonics plates; the black box shows the study area. (b) Paleomagnetic rotations domains showing the Maipo and Arauco Oroclines (Arriagada et al 2009). (c) Geological map, the red boxes indicates the sampling areas. BBFZ: Bio-Bio Fault Zone(Rehak et al., 2008); ML: Maule Lineament and IL: Itata Lineament (Willner et al. 2005). (For interpretation of the references to color in this figure legend, the reader is referred to the Web version of this article.) 
in the Western and the Eastern Series (Aguirre et al., 1972 and Fig. 1C). The Eastern Series consists of meta-greywacke and metapelite and is almost devoid of metabasites. It shows metamorphic gradients from very low-grade rocks to amphibolite - granulite gneisses, related to the proximity of Late Paleozoic calcalkaline granitoids (Hervé et al., 1988;
Beck et al., 1991; Martin et al., 1999). Based on petrological, structural, and age characteristics, the Eastern Series is interpreted as resulting from subduction-related accretion and deformation of former passive margin sediments, followed by intrusion of arc granitoids (Hervé et al., 1988; Willner et al., 2005; Glodny et al., 2006). The Western Series
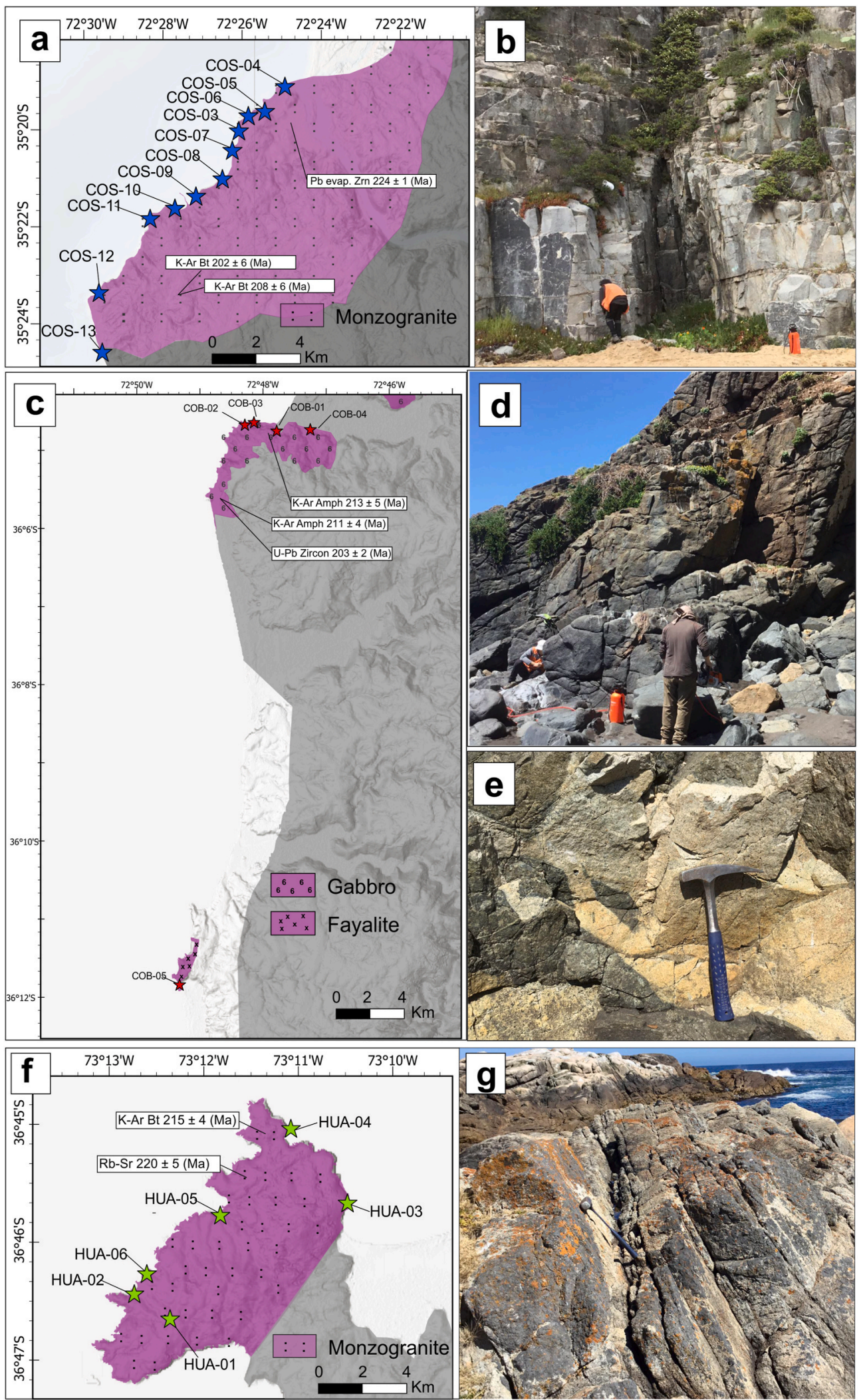

Fig. 2. (a) Geological map of Constitución Granite. Ages from Willner et al. (2005) and Gana and Hervé (1983). (b) Outcrop view. (c) Geological map of Cobquecura Pluton. Radiometric ages from Vásquez et al., (2005) and 2011. (d) Outcrop view. (e) Felsic intrusion in gabbro. (f) Geological map of Hualpén Stock. Isotopic ages from Lucassen et al. (2004) and Hervé et al. (1988). (g) Outcrop view with clearly developed subparallel joints. Blue, red and green stars show sampling locations in each studied unit. (For interpretation of the references to color in this figure legend, the reader is referred to the Web version of this article.) 
represents the accretionary prism and is characterized by meta-greywackes interlayered with lenses of oceanic crust. The latter consist of mainly green-schist, rare blue-schist and associated Fe-Mn-rich meta-sediments, minor meta-chert and serpentinite. All these rocks are pervasively deformed and characterized by a second flat-lying transposition foliation. The Western Series is interpreted as a paleoaccretionary complex built by basal accretion and the Eastern Series shows all characteristics of frontally accreted sediments (Glodny et al., 2005; Richter et al., 2007).

Subsequently, after the definitive amalgamation of Pangea Supercontinent in late Permian, the previously formed Orogen collapsed as result of the drastic diminish in plate convergence, leading to the formation of elongated NNW-SSE extensional basins and large volumes of mostly anorogenic silic magmatism of the Choiyoi province (Uliana and Biddle 1988; Mpodozis and Ramos 1989; Mpodozis and Kay 1990; Suarez and Bell 1992)

First evidence of post Gondwana magmatism in Southern Central Chile is a series of isolated Upper Triassic high silica granitoids that crops out in Coastal Cordillera (Vasquez et al., 2011). Their compositions are mainly monzogranitic (Hervé et al., 1988), except for the Cobquecura Pluton, which also comprises gabbroic rocks (Hervé et al., 1988; Vásquez et al., 2009). These plutonic rocks crop out on both the western and the eastern flanks of the Cordillera de la Costa (Hervé et al., 1988; Vásquez and Franz 2008). This granitoid intrudes exclusively Late Paleozoic magmatic and metamorphic rocks of the previous tectonic cycle, and are closely associated with small Upper Triassic sedimentary basins with an incipient northwest orientation (Charrier 1979; Hervé et al., 1988).

The Early Mesozoic Constitución, Cobquecura and Hualpén plutons were all emplaced at shallow crustal levels, display narrow contact aureoles, lack indications for deformation or metamorphism, are postkinematic with respect to the main foliation of their metamorphic host rocks, and are exposed discontinuously in only small areas (Vásquez et al., 2011). The coincidence of the Triassic plutonic bodies with NW-SE trending lineaments have led Vázquez et al. (2011) to propose oblique subduction conditions generating extension-related NW-SE structures, which in turn facilitated the ascent of magmas followed by an episode of slab steepening at around 210-197 Ma (Fig. 1C). Extensional conditions was maintained for most of Jurassic and Early Cretaceous time, permitting the dominance of extensional tectonic conditions on the continental margin, intense magmatic activity along the arc, and abundant sedimentation in the backarc basin. These basins were inverted during the Late Cretaceous compressive deformation and created a major regional unconformity (Charrier et al., 2009).

The Constitución Granite $\left(35.36^{\circ} \mathrm{S}, 72.42^{\circ} \mathrm{W}\right.$; Fig. 2a and b) is a homogeneous, K- feldspar-porphyric biotite-monzogranite (Vásquez et al., 2011). It is intruded into metapelites and metabasites of the Late Paleozoic metamorphic basement. The Constitución Granite has been dated as $208 \pm 6 \mathrm{Ma} ; 202 \pm 6 \mathrm{Ma}$ by K-Ar in biotite by Gana and Hervé (1983). Older ages of $224 \pm 1$ Ma were obtained using $\mathrm{Pb}$ evaporation on zircon by Willner et al. (2005).

The Cobquecura Pluton is located to the south of Constitución Granite $\left(-36^{\circ} 10^{\prime} \mathrm{S}, 72^{\circ} 47^{\prime} \mathrm{W}\right.$; Fig. $2 \mathrm{c}$ and d), intruded into the metasedimentary metamorphic basement. The pluton, compared with other intrusions of the area, shows a bi-modal composition with gabbroic and granitic end-members, and less abundant hybrid rocks consisting of tonalites evidencing mixing (resorbed cores of plagioclase) and mingling (composite dikes, mafic pillow-shaped enclaves and net-vein complexes) processes. This rock additionally contains a few metamorphic enclaves (Vásquez and Franz 2008). Abundant pillows of mafic composition in granitic magmas are typical for the mingling of coeval felsic and mafic magmas (Fig. 2d). Granites contain fayalitic olivine, Fe-rich clinopyroxene, amphibole, biotite, and ilmenite, whereas gabbros are mostly composed of Mg-rich piroxenes, amphiboles and minor forsteritic olivine and biotite (Vásquez et al., 2011). The age of the Cobquecura magmatism is fairly well constrained. A K-Ar age of $211 \pm 4$ Ma on ferroedenitic amphibole was obtained for a fayalite granodiorite, a K-Ar Mg-hornblende age of $213 \pm 5$ Ma for a gabbro (Vásquez et al., 2005) and $209 \pm 2 \mathrm{Ma} ; 203 \pm 2 \mathrm{Ma}$ (sample 04-22) by U-Pb zircon (Vásquez et al., 2011). Field observations, namely the evidence for magma mingling, show that the mafic and felsic magmas of the Cobquecura Pluton were strictly contemporaneous. This inference is backed up by major element correlations for fayalite granitoids and gabbro, suggesting a co-magmatic evolution for all Cobquecura igneous rocks (Vásquez and Franz 2008).

The Hualpén Stock is located at the mouth of the Biobío River, which follows a NW-SE-oriented lineament. It intruded into metapelites of the Paleozoic metamorphic basement and is a homogeneous two mica-monzogranite (Fig. $2 \mathrm{f}$ and g; Creixell et al., 2002). There are precise geochronologic data for the stock $(215 \pm 4 \mathrm{Ma}, \mathrm{K}-\mathrm{Ar}$ in biotite from Hervé et al., 1988; meanwhile an age by Rb-Sr mineral data $220 \pm$ 5-222 \pm 2 Ma has been mentioned by Lucassen et al., 2004, and $227 \pm 7$ Ma in Rb-Sr mineral data from Glodny et al., 2006).

\section{Sampling and methodology}

Paleomagnetic sampling was performed during two field seasons when more than 120 oriented cores were collected. The sampling was carried out with a portable gasoline-powered drill system, and all samples were oriented in situ using magnetic and solar compasses. The collection of oriented cores belongs to 23 stations and at least five different samples were obtained from each sampling site.

Magnetic remanences were measured with a JR6 spinner magnetometer in the Paleomagnetism Laboratory "Daniel A. Valencio" of the IGeBA (UBA-CONICET) and with the "SushiBar" magnetometer (a fully automated system based on a $2 \mathrm{G}$ Enterprises, Inc., three-axis superconducting magnetometer) in the Geophysics Laboratory of LudwigMaximilians-Universität (Munich). Thermal demagnetizations were carried out by an ASC furnace and alternating fields (AF) demagnetizations were done with a tumbler LD-A (AGICO Inc) alternating field demagnetizer. AGICO "Remasoft" software was used to analyse the magnetic behaviors of the samples and determine the characteristic remanent magnetizations (ChRM).

The ChRMs were determined, as described in Ruiz González et al. (2020), only in their geographic coordinates due to the lack of paleohorizontal evidence. Characteristic remanence directions (ChRM) with less than $15^{\circ}$ of Maximum Angular Deviation (MAD) calculated using at least 3 demagnetization steps were exclusively accepted for the analysis (Kirschvink 1980). Samples with less than 20\% of the NRM intensity after steps of $20 \mathrm{mT}$ or $300{ }^{\circ} \mathrm{C}$ of demagnetization were discarded, considering that low coercivities (Hc) or low un-blocking temperatures could belong to spurious magnetic components. The paleomagnetic analysis was performed using the ChRMs of the samples without averaging them per site, according to Deenen et al. (2011), and each pluton was considered as belonging to the same tectonic block (Fig. 1C). A cut-off angle of $40^{\circ}$ was applied to the ChRM to filter transitional and spurious data (Wilson et al., 1972). In order to validate these results, a reversal test was carried out with the ChRM directions inside the cut off angle.

To discuss the tectonic implications of the paleomagnetic results and detect possible spatial variations in the amount of tectonic rotation and flattening values with respect to stable South America for each pluton, we used Demarest Harold (1983). The references paleopoles for South America for 210 Ma (Cobquecura Pluton) and 220 Ma (Constitución Granite and Hualpén Stock) were taken from Torsvik et al. (2012). The mean directions for each locality and the tectonic rotations and inclination errors are given in Tables 1-4.

Nine sites were sampled in the granite (COS3-COS12, 50 cores) and one (COS13, 5 cores) in the host rock (Fig. 2a). Sampling covered mainly the western sector of the pluton with a distance between adjacent sites generally around hundreds of meters $(660 \mathrm{~m})$ up to $3 \mathrm{~km}$. The Cobquecura Pluton was sampled at 4 localities (COB1 to COB4) at the northern 
Table 1

Paleomagnetic results in geographic coordinates for the Constitución Granite (Fisher, 1953).

\begin{tabular}{|c|c|c|c|c|c|c|}
\hline Sample & Lat. & Long. & Lithology & Dec & Inc & MAD \\
\hline \multicolumn{7}{|c|}{ Constitución Pluton ( 210 Ma) } \\
\hline COS-03-1 & -35.333 & -72.435 & Monzogranite & 56.4 & -53.8 & 7.5 \\
\hline COS-03-2 & -35.333 & -72.435 & Monzogranite & --- & --- & --- \\
\hline COS-03-3 & -35.333 & -72.435 & Monzogranite & --- & ---- & --- \\
\hline COS-03-4 & -35.333 & -72.435 & Monzogranite & --- & ---- & --- \\
\hline COS-03-5 & -35.333 & -72.435 & Monzogranite & --- & ---- & ---- \\
\hline COS-04-1 & -35.318 & -72.415 & Monzogranite & 11. & -41.2 & 9.1 \\
\hline COS-04-2 & -35.318 & -72.415 & Monzogranite & 352.3 & -19.3 & 9.4 \\
\hline COS-04-3 & -35.318 & -72.415 & Monzogranite & --- & --- & --- \\
\hline COS-04-4 & -35.318 & -72.415 & Monzogranite & 12.6 & -34.7 & 9.8 \\
\hline COS-04-5 & -35.318 & -72.415 & Monzogranite & 307.2 & -27.0 & 8.5 \\
\hline COS-05-1 & -35.326 & -72.424 & Monzogranite & 19.1 & -21.5 & 8.1 \\
\hline COS-05-2 & -35.326 & -72.424 & Monzogranite & 274.2 & -67.5 & 4.8 \\
\hline COS-05-3 & -35.326 & -72.424 & Monzogranite & --- & --- & --- \\
\hline COS-05-4 & -35.326 & -72.424 & Monzogranite & 34.1 & -49.6 & 3.5 \\
\hline COS-05-5 & -35.326 & -72.424 & Monzogranite & 8.4 & -50.7 & 9.4 \\
\hline COS-06-1 & -35.328 & -72.431 & Monzogranite & 241.9 & 42.7 & 10.7 \\
\hline COS-06-2 & -35.328 & -72.431 & Monzogranite & 41.0 & -41.0 & 9.6 \\
\hline COS-06-3 & -35.328 & -72.431 & Monzogranite & 19.5 & -71.3 & 8. \\
\hline COS-06-4 & -35.328 & -72.431 & Monzogranite & 12.3 & 23.7 & 9.5 \\
\hline COS-06-5 & -35.328 & -72.431 & Monzogranite & 16.2 & -47.4 & 14.2 \\
\hline COS-07-1 & -35.340 & -72.437 & Monzogranite & 352.2 & -37.0 & 7.4 \\
\hline COS-07-2 & -35.340 & -72.437 & Monzogranite & --- & ---- & --- \\
\hline COS-07-3 & -35.340 & -72.437 & Monzogranite & ---- & ---- & ---- \\
\hline COS-07-4 & -35.340 & -72.437 & Monzogranite & 353.3 & -21.5 & 4.8 \\
\hline COS-07-5 & -35.340 & -72.437 & Monzogranite & --- & ---- & ---- \\
\hline COS-08-1 & -35.350 & -72.441 & Monzogranite & 346.0 & -56.7 & 8.3 \\
\hline COS-08-2 & -35.350 & -72.441 & Monzogranite & 47.3 & -12.5 & 3.9 \\
\hline COS-08-3 & -35.350 & -72.441 & Monzogranite & 293.8 & -7.2 & 8.8 \\
\hline COS-08-4 & -35.350 & -72.441 & Monzogranite & 25.1 & -51.2 & 9.9 \\
\hline COS-08-5 & -35.350 & -72.441 & Monzogranite & 9.9 & -65.0 & 8.1 \\
\hline COS-09-1 & -35.356 & -72.453 & Monzogranite & 24.3 & -57.2 & 10. \\
\hline COS-09-2 & -35.356 & -72.453 & Monzogranite & 22.6 & -49.3 & 6.8 \\
\hline COS-09-3 & -35.356 & -72.453 & Monzogranite & 19.0 & -61.3 & 9. \\
\hline COS-09-4 & -35.356 & -72.453 & Monzogranite & 11.3 & -71.4 & 10.3 \\
\hline COS-09-5 & -35.356 & -72.453 & Monzogranite & 13.6 & -66.4 & 8.3 \\
\hline COS-10-1 & -35.360 & -72.462 & Monzogranite & 26.2 & -65.3 & 9.8 \\
\hline COS-10-2 & -35.360 & -72.462 & Monzogranite & 27.1 & -67.8 & 6.7 \\
\hline COS-10-3 & -35.360 & -72.462 & Monzogranite & 134.1 & -79.9 & 9.4 \\
\hline COS-10-4 & -35.360 & -72.462 & Monzogranite & 45.6 & -64.4 & 8.8 \\
\hline COS-10-5 & -35.360 & -72.462 & Monzogranite & 124.5 & -69.9 & 9.5 \\
\hline COS-11-1 & -35.363 & -72.472 & Monzogranite & 60.8 & -65.0 & 9.6 \\
\hline COS-11-2 & -35.363 & -72.472 & Monzogranite & 317.3 & -45.7 & 7.4 \\
\hline COS-11-3 & -35.363 & -72.472 & Monzogranite & 153.7 & 47.5 & 4.1 \\
\hline
\end{tabular}




\begin{tabular}{lcclccc} 
COS-11-4 & -35.363 & -72.472 & Monzogranite & 122.5 & -50.1 & 14.4 \\
\hline COS-11-5 & -35.363 & -72.472 & Monzogranite & 81.3 & -56.7 & 3.9 \\
COS-12-1 & -35.389 & -72.494 & Monzogranite & 14.0 & -65.4 & 7.4 \\
COS-12-2 & -35.389 & -72.494 & Monzogranite & 85.5 & -71.0 & 7.8 \\
COS-12-3 & -35.389 & -72.494 & Monzogranite & 31.1 & -77.8 & 9.7 \\
COS-12-4 & -35.389 & -72.494 & Monzogranite & 19.2 & -43.3 & 8.2 \\
COS-12-5 & -35.389 & -72.494 & Monzogranite & 64.9 & -53.1 & 6.9 \\
COS-13-1 & -35.409 & -72.492 & Milonite & ---- & ---- & ---- \\
COS-13-2 & -35.409 & -72.492 & Milonite & ---- & ---- & ---- \\
\hline COS-13-3 & -35.409 & -72.492 & Milonite & 67.6 & 41.20 & 5.6 \\
\hline COS-13-4 & -35.409 & -72.492 & Milonite & ---- & ---- & ---- \\
COS-13-5 & -35.409 & -72.492 & Milonite & ---- & ---- & ---- \\
\hline Mean & $\mathbf{N} / \mathbf{n}$ & Dec & $\mathbf{I n c}$ & $\mathbf{\alpha 9 5}$ & $\mathbf{k}$ \\
\hline COS & $\mathbf{3 5 / 5 5}$ & $\mathbf{1 5 . 4}$ & $\mathbf{- 5 8 . 2}$ & $\mathbf{7 . 2}$ & $\mathbf{1 2}$ \\
\hline
\end{tabular}

Lat., Long.: site location (to the nearest half a minute). (n/N): number of samples involved in statistics/ total number of samples. Decl., Incl.: declination and inclination of paleomagnetic vector in geographical coordinates. $\alpha 95$ : cone of $95 \%$ confidence level around mean direction (Fisher, 1953). k: precision parameter (Fisher, 1953). Sites not considered for mean calculation are highlighted in gray. Samples with (---) indicates that ChRM could not be obtained.

part of the pluton and one (COB5) at the southern part near to Santa Rita (30 cores in total) (Fig. 2c). Also, six sites were drilled in Hualpén stock located $79 \mathrm{~km}$ to the south near to Concepción city (HUA-1 to HUA-6; Fig. 2f). A total of 27 independently oriented cores were obtained.

\section{Characteristic directions}

In this section we analyse the paleomagnetic data obtained from the Constitución, Cobquecura and Hualpén plutons. In spite of the fact that in the three areas a characteristic remanence direction could be obtained of normal and reversed polarity and all correspond to Upper Triassic rocks, each pluton will be analyzed separately.

\subsection{Constitución Granite}

Characteristic remanence directions were obtained from most of the samples of the monzogranite (see Table 1). On the other hand, four of the five samples obtained from the host rock presented an erratic behavior during demagnetization procedures (Fig. 3f). The unique component obtained (sample COS13-3, see Table 1) shows an anomalous direction and was discarded for tectonic analysis.

For samples from the Constitución Granite both demagnetizing methods were efficient in isolating a stable univectorial normal or reverse polarity remanent magnetization (Fig. 3). The ChRM was recovered by thermal demagnetization in the temperature range $450-530{ }^{\circ} \mathrm{C}$, or the range $10-60 \mathrm{mT}$ under AF cleaning (Fig. 3). The characteristic component was determined with MAD under $10^{\circ}$ in most cases (see Table 1). Since both polarities were recorded, the McFadden and McElhinny (1990) reversal test was performed. An indeterminate result was obtained with a $\gamma_{\text {observed }}=12.5^{\circ}$ and a $\gamma_{\text {critical }}=28.1^{\circ}$.

The mean direction for the Constitución Granite obtained after ruling out eight ChRM considered anomalous differs from the expected Late Triassic paleomagnetic field suggesting a clockwise tectonic rotation of $13.5 \pm 11.5^{\circ}$ (Fig. 3 II, see Table 4).

\subsection{Cobquecura Pluton}

Samples from the pluton exhibited stable magnetic behaviors that allowed us to define ChRM (see Table 2). These were mostly determined with $\mathrm{MAD}<11^{\circ}$. Both demagnetization methods were efficient in discriminating the magnetic components. In most cases, a unique ChRM was isolated at temperatures/maximum alternating fields ranges of $180-580{ }^{\circ} \mathrm{C}$ or $10-60 \mathrm{mT}$ (Fig. $4 \mathrm{I}$ a-b and d-f). Sometimes thermal demagnetization showed an abrupt decay of the remanence towards the origin of coordinates above $500{ }^{\circ} \mathrm{C}$ (Fig. 4I-e and f). Samples from COB2 record two components, one of lower temperature $\left(180-350{ }^{\circ} \mathrm{C}\right)$ and other between 400 and $580{ }^{\circ} \mathrm{C}$ (Fig. 4I-c). The lower temperature component shows scattered directions and was discarded from further analysis (see Table 2). These differences in the demagnetization behaviors between different sites reflect the widely variable textural and compositional lithology of the pluton.

Remanences of this intrusive body record both polarities of the paleomagnetic field (Fig.4II), although positive inclinations predominate. The reversal test of McFadden and McElhinny (1990) was performed with an indeterminate result: $\gamma_{\text {observed }}=19^{\circ}$ and a $\gamma_{\text {critical }}=$ $21.3^{\circ}$. The mean direction obtained for the Cobquecura Pluton differs from the expected direction (see star in Fig. 4II and Table 4) suggesting a $41.3 \pm 15^{\circ}$ clockwise rotation (Fig. 4 II).

\subsection{Hualpén Stock}

Characteristic remanence directions of both polarities were obtained from most of the samples of the Hualpén Stock (see Table 3, Fig. 5). In most cases, a unique component decaying towards the origin could be isolated between 180 and $580{ }^{\circ} \mathrm{C}$ or $10-60 \mathrm{mT}$ (Fig. 5I). Sometimes an abrupt decay during thermal demagnetization was observed above $500{ }^{\circ} \mathrm{C}$ (Fig. 5I-b and e) suggesting that titano-magnetite is the main mineral carrying the remanence. A few samples from the stock record two components: one of lower temperature $\left(180-300{ }^{\circ} \mathrm{C}\right)$ and another 
Table 2

Paleomagnetic results from Cobquecura Pluton.

\begin{tabular}{|c|c|c|c|c|c|c|}
\hline Sample & Lat. & Long. & Lithology & Dec & Inc & MAD \\
\hline \multicolumn{7}{|c|}{ Cobquecura Pluton ( 209 Ma) } \\
\hline COB1-1 & -36.079 & -72.796 & Gabbro & 26.6 & -12.6 & 8.6 \\
\hline COB1-2 & -36.079 & -72.796 & Gabbro & ---- & ---- & ---- \\
\hline $\mathrm{COB} 1-3 \mathrm{C}$ & -36.079 & -72.796 & Gabbro & 9.3 & -56.3 & 10.3 \\
\hline COB1-4 & -36.079 & -72.796 & Gabbro & 87.3 & -66.6 & 5.8 \\
\hline COB1-5 & -36.079 & -72.796 & Gabbro & 83.6 & -67.8 & 9.4 \\
\hline COB1-6A & -36.079 & -72.796 & Gabbro & 48.6 & -73.1 & 8.4 \\
\hline $\mathrm{COB} 2-1^{1}$ & -36.077 & -72.802 & Gabbro & 139.6 & 1.1 & 2.6 \\
\hline COB2- $1^{\mathrm{h}}$ & -36.077 & -72.802 & Gabbro & 47.8 & -56.1 & 1.8 \\
\hline $\mathrm{COB} 2-2 \mathrm{C}^{\mathrm{l}}$ & -36.077 & -72.802 & Gabbro & 74.2 & -3.7 & 8.6 \\
\hline COB2-2C & -36.077 & -72.802 & Gabbro & 337.4 & 4.4 & 4 \\
\hline $\mathrm{COB} 2-2 \mathrm{C}^{\mathrm{h}}$ & -36.077 & -72.802 & Gabbro & 333.1 & -40.2 & 9.4 \\
\hline $2 \mathrm{COB}-2$ & -36.077 & -72.802 & Gabbro & 222.1 & -34 & 10.8 \\
\hline COB2-3 $3^{\mathrm{h}}$ & -36.077 & -72.802 & Gabbro & 49.9 & -62.9 & 5.3 \\
\hline $\mathrm{COB} 2-3^{1}$ & -36.077 & -72.802 & Gabbro & 96.1 & -37 & 4.2 \\
\hline COB2-4 & -36.077 & -72.802 & Gabbro & 31.5 & -11.1 & 3.2 \\
\hline COB2-5 & -36.077 & -72.802 & Gabbro & 15.1 & 7.4 & 4.9 \\
\hline COB2-6 & -36.077 & -72.802 & Gabbro & 18.8 & -64.2 & 6.2 \\
\hline COB3-1 & -36.078 & -72.805 & Gabbro & 122.1 & 51.5 & 8.4 \\
\hline COB3-2 & -36.078 & -72.805 & Gabbro & ---- & ---- & ---- \\
\hline COB3-3 & -36.078 & -72.805 & Gabbro & 27.7 & -43.8 & 10.3 \\
\hline COB3-4 & -36.078 & -72.805 & Gabbro & 267.7 & 79.6 & 8.9 \\
\hline COB3-5 & -36.078 & -72.805 & Gabbro & 153.8 & 78.3 & 5.1 \\
\hline COB3-6B & -36.078 & -72.805 & Gabbro & 318.8 & 9 & 8.7 \\
\hline COB4-1 & -36.079 & -72.788 & Fayalite & ---- & --- & ---- \\
\hline COB4-2 & -36.079 & -72.788 & Fayalite & 38.3 & -61.1 & 5.2 \\
\hline COB4-2A & -36.079 & -72.788 & Fayalite & 38 & -58.8 & 9.8 \\
\hline COB4-3 & -36.079 & -72.788 & Fayalite & 40.6 & -72.4 & 3.1 \\
\hline COB4-4 & -36.079 & -72.788 & Fayalite & 168.3 & -73.8 & 13 \\
\hline COB4-5 & -36.079 & -72.788 & Fayalite & 45.6 & -60.3 & 8.2 \\
\hline COB5-1B & -36.197 & -72.822 & Gabbro & 272.9 & 66.4 & 9.3 \\
\hline COB5-2 & -36.197 & -72.822 & Gabbro & 271.5 & 69 & 6.3 \\
\hline COB5-3 & -36.197 & -72.822 & Gabbro & ---- & --- & ---- \\
\hline COB5-4 & -36.197 & -72.822 & Gabbro & 280 & 64.2 & 3.2 \\
\hline COB5-5 & -36.197 & -72.822 & Gabbro & 275.6 & 72.7 & 2.5 \\
\hline \multicolumn{2}{|c|}{ Mean } & $\mathbf{N} / \mathbf{n}$ & Dec & Inc & $\alpha 95$ & $\mathbf{k}$ \\
\hline \multicolumn{2}{|c|}{$\mathrm{COB}$} & $22 / 29$ & 232.1 & 68.4 & 6.7 & 28 \\
\hline
\end{tabular}

Lat., Long.: site location (to the nearest half a minute). (n/ $\mathrm{N})$ : number of samples involved in statistics/ total number of samples. Decl., Incl.: declination and inclination of paleomagnetic vector in geographical coordinates. $\alpha 95$ : cone of $95 \%$ confidence level around mean direction (Fisher, 1953). k: precision parameter (Fisher, 1953). Sites not considered for mean calculation are highlighted in gray. ${ }^{\text {h. }}$ High temperature component. ${ }^{\text {. }}$ Low temperature component. Samples with (---) indicates that ChRM could not be obtained. 
Table 3

Characteristic remanence directions from Hualpén Stock.

\begin{tabular}{|c|c|c|c|c|c|c|}
\hline Sample & Lat. & Long. & Lithology & Dec & Inc & MAD \\
\hline \multicolumn{7}{|c|}{ Hualpén Stock ( 217 Ma) } \\
\hline HUA1-1 & -36.777 & -73.206 & Monzogranite & 348.9 & -80.1 & 7.6 \\
\hline HUA1-2 & -36.777 & -73.206 & Monzogranite & 3.8 & 25.6 & 7.8 \\
\hline HUA1-3 & -36.777 & -73.206 & Monzogranite & 285.2 & -86.5 & 7.9 \\
\hline $\begin{array}{c}\text { HUA2- } \\
1 B\end{array}$ & -36.774 & -73.212 & Monzogranite & 319.2 & -57.3 & 6.3 \\
\hline HUA2-2 & -36.774 & -73.212 & Monzogranite & 32.3 & -62.1 & 7.5 \\
\hline HUA2-3 $3^{1}$ & -36.774 & -73.212 & Monzogranite & 319.3 & -60.3 & 9 \\
\hline HUA2-3 $3^{\mathrm{h}}$ & -36.774 & -73.212 & Monzogranite & 176.7 & 64.6 & 10 \\
\hline HUA2-4 ${ }^{\text {h }}$ & -36.774 & -73.212 & Monzogranite & 198.5 & 64.8 & 6.7 \\
\hline HUA2-4 ${ }^{1}$ & -36.774 & -73.212 & Monzogranite & 352.4 & -51.3 & 3 \\
\hline HUA2-5 & -36.774 & -73.212 & Monzogranite & 180.7 & 33.6 & 8.5 \\
\hline HUA3-1 ${ }^{1}$ & -36.761 & -73.175 & Monzogranite & 264.4 & 3.2 & 0.4 \\
\hline HUA3-1 ${ }^{\mathrm{h}}$ & -36.761 & -73.175 & Monzogranite & 41.9 & 57.6 & 6 \\
\hline HUA3-2 & -36.761 & -73.175 & Monzogranite & 254.6 & 40 & 9.4 \\
\hline HUA3-3 & -36.761 & -73.175 & Monzogranite & 278.2 & 73.8 & 5.4 \\
\hline HUA3-4 & -36.761 & -73.175 & Monzogranite & 175.5 & -21 & 13.9 \\
\hline HUA3-5 & -36.761 & -73.175 & Monzogranite & 335.7 & -28.2 & 11.9 \\
\hline HUA3-6 & -36.761 & -73.175 & Monzogranite & 326.9 & 39 & 6.8 \\
\hline HUA4-1 & -36.751 & -73.185 & Monzogranite & 228.4 & 42.6 & 2.2 \\
\hline HUA4-2 & -36.751 & -73.185 & Monzogranite & ---- & ---- & ---- \\
\hline HUA4-3 & -36.751 & -73.185 & Monzogranite & 257.8 & 28.3 & 3 \\
\hline HUA4-4 & -36.751 & -73.185 & Monzogranite & 111.5 & 57.5 & 3.3 \\
\hline HUA4-5 & -36.751 & -73.185 & Monzogranite & 19.7 & 36.6 & 12.4 \\
\hline HUA5-1 & -36.763 & -73.197 & Monzogranite & 43.4 & -75.4 & 9 \\
\hline HUA5-2 & -36.763 & -73.197 & Monzogranite & 3.4 & -55.3 & 8 \\
\hline HUA5-3 & -36.763 & -73.197 & Monzogranite & 331.8 & -58.5 & 9.2 \\
\hline HUA5-4 ${ }^{1}$ & -36.763 & -73.197 & Monzogranite & 341.8 & -63.2 & 11.2 \\
\hline HUA $5-4^{\text {h }}$ & -36.763 & -73.197 & Monzogranite & 227.5 & 19.2 & 8.6 \\
\hline HUA6-1 & -36.771 & -73.210 & Monzogranite & 7.4 & -48 & 6.9 \\
\hline HUA6-21 & -36.771 & -73.210 & Monzogranite & 324.1 & -24.6 & 6.3 \\
\hline HUA6- $2^{\mathrm{h}}$ & -36.771 & -73.210 & Monzogranite & 63.8 & 21.6 & 12.8 \\
\hline HUA6-4 & -36.771 & -73.210 & Monzogranite & 291.1 & 51.1 & 9 \\
\hline HUA6-5 & -36.771 & -73.210 & Monzogranite & 254.6 & 68.1 & 14.7 \\
\hline \multicolumn{2}{|c|}{ Mean } & $\mathbf{N} / \mathbf{n}$ & Dec & Inc & $\alpha 95$ & $\mathbf{k}$ \\
\hline \multicolumn{2}{|c|}{ HUA } & $17 / 32$ & 165.6 & 60 & 9.9 & 14 \\
\hline
\end{tabular}

Same as Table 2

between 350 and $580{ }^{\circ} \mathrm{C}$ (Fig. 5I-f). In contrast with the Cobquecura Pluton, most of the remanence of lower temperature observed in the Hualpén Stock record a direction similar to the samples with a unique component (see Table 3).

Since both polarities were recorded, the reversal test of McFadden and McElhinny (1990) was performed. An indeterminate result was obtained with an $\gamma_{\text {observed }}=2.6^{\circ}$ and a $\gamma_{\text {critical }}=24.1^{\circ}$. The mean direction obtained from the stock, after applying a cut-off angle of $45^{\circ}$ to filter transitional and spurious data, differs from the expected paleomagnetic field for the Late Triassic suggesting that the stock is $16 \pm$ $16.3^{\circ}$ counter-clockwise rotated (Fig. 5II and Table 4). 


\section{Constitución Pluton ( 210 Ma)}

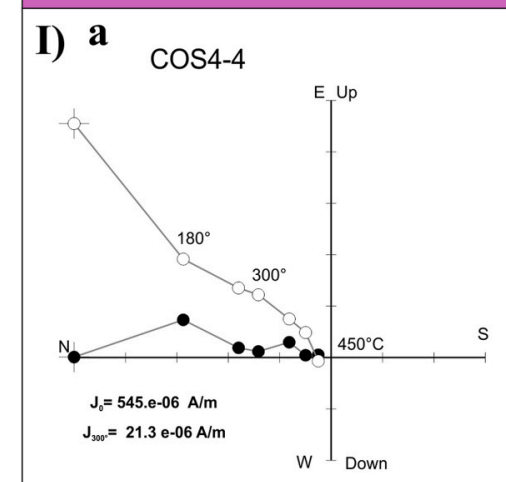

b $\cos 9-4$
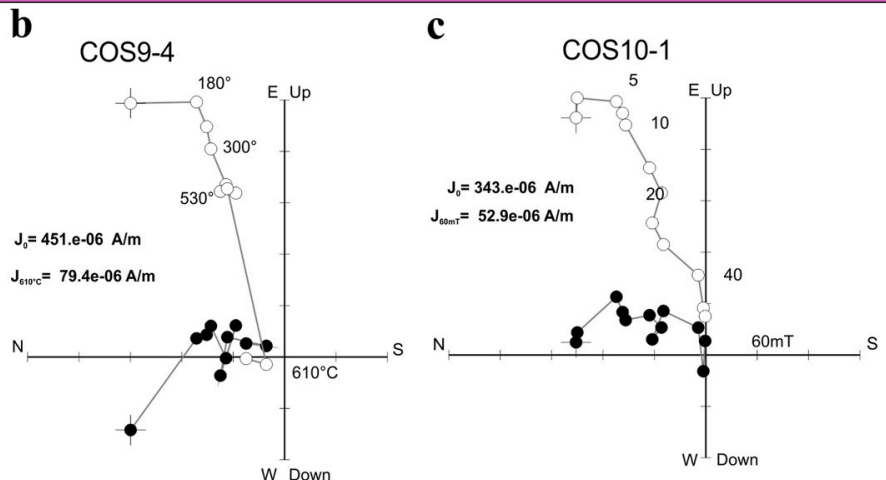

d

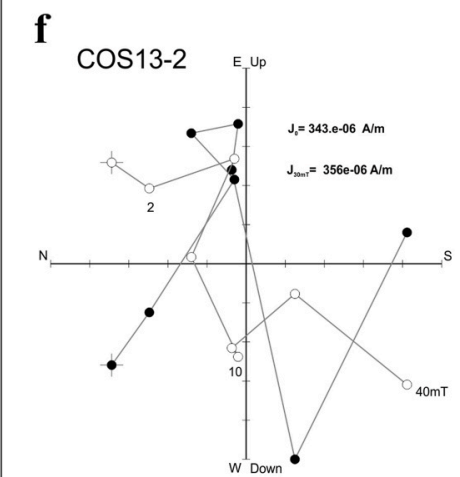

g

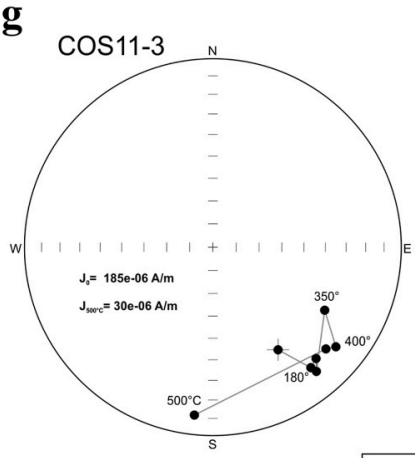

i

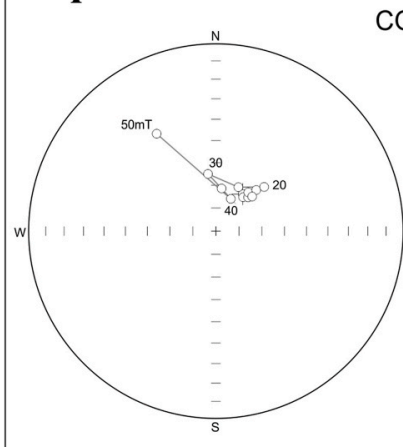

$\cos 11-1$

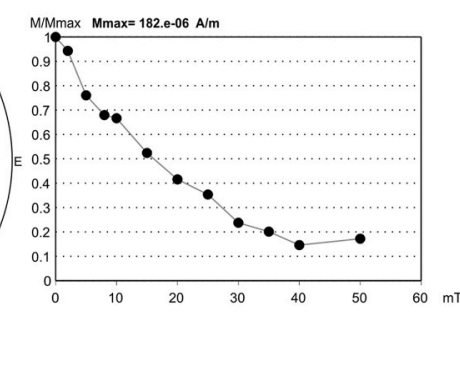

h

II)

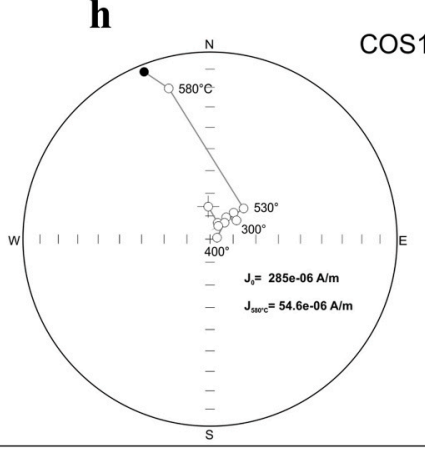

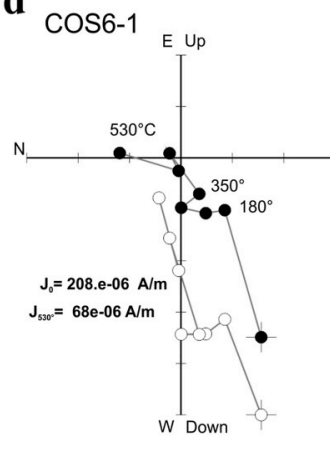

$\operatorname{OS} 10-5$

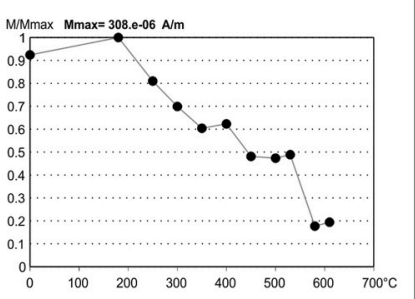

Fig. 3. (I) Paleomagnetic behavior observed for samples from the Constitución Granite (a-e and g-i) and the host rock (f). The open (full) symbols in the Zijderveld diagram correspond to the projection in the vertical (horizontal) plane; in the stereonet open (full) symbols indicate up-wards (downwards) inclination. (II) To the left directions of the characteristic remanence of the specimens of Constitución Granite, samples discarded are showing in red; at right mean direction carried to a single polarity. Open (filled) symbols correspond to projection onto the upper (lower) hemisphere. The yellow star corresponds to the references direction. (For interpretation of the references to color in this figure legend, the reader is referred to the Web version of this article.)

\section{Tectonic rotations}

For each locality, tectonic rotations and inclination anomalies were calculated according to Demarest Harold (1983) using the reference poles for $210 \mathrm{Ma}$ and $220 \mathrm{Ma}$ from Torsvik et al. (2012) transported to South American coordinates through the translations proposed in that work (see Table 4).

The data obtained indicate an increase in the magnitude of a clockwise tectonic rotation between the Constitución Granite and the Cobquecura Pluton from $\sim 13^{\circ}$ up to $41^{\circ}$. This is consistent with previous paleomagnetic data (Beck et al. 1986, 1990; Charrier et al., 1996; Goguitchaichvili et al., 2000; Parada et al., 2005; Astudillo et al., 2009; Arriagada et al., 2013) (see Fig. 6). On the other hand, the Hualpén Stock recorded minor counter-clockwise tectonic rotation to no tectonic rotation. The spatial variation in the magnitude and sense of rotations shows that the Chilean Andes region between $30^{\circ}$ and $37^{\circ} \mathrm{S}$ did not behave as a rigid block.

Previous paleomagnetic data show no significant systematic rotations in Chile between approximately $31^{\circ}$ and $33^{\circ} \mathrm{S}$ (Dashwood and Taylor 2005; Peña et al., 2011; Arriagada et al., 2013, Fig. 6). To the south of this last segment, a new zone of clockwise tectonic rotations is observed between approximately $33^{\circ}$ and $36^{\circ} \mathrm{S}$ (see Arriagada et al., 2013 and references therein). This last area is limited to the north by the Argentinian Precordillera, where one of the orogenic maximums in Neogene horizontal shortening is observed (Fig. 6b). Horizontal shortening decreases gradually between $33^{\circ}$ and $36^{\circ} \mathrm{S}$ (Giambiagi et al., 2012). Dewey and Lamb (1992) interpreted that this decrease in the horizontal shortening would be responsible for a clockwise oroclinal rotation of the trench and volcanic arc between $34^{\circ}$ and $39^{\circ} \mathrm{S}$, and the formation of the Maipo Orocline (Arriagada et al., 2009). This hypothesis is in agreement with the previous paleomagnetic data (Beck et al. 1986, 1990; Charrier et al., 1996; Goguitchaichvili et al., 2000; Parada 


\section{Cobquecura Pluton ( 209 Ma)}

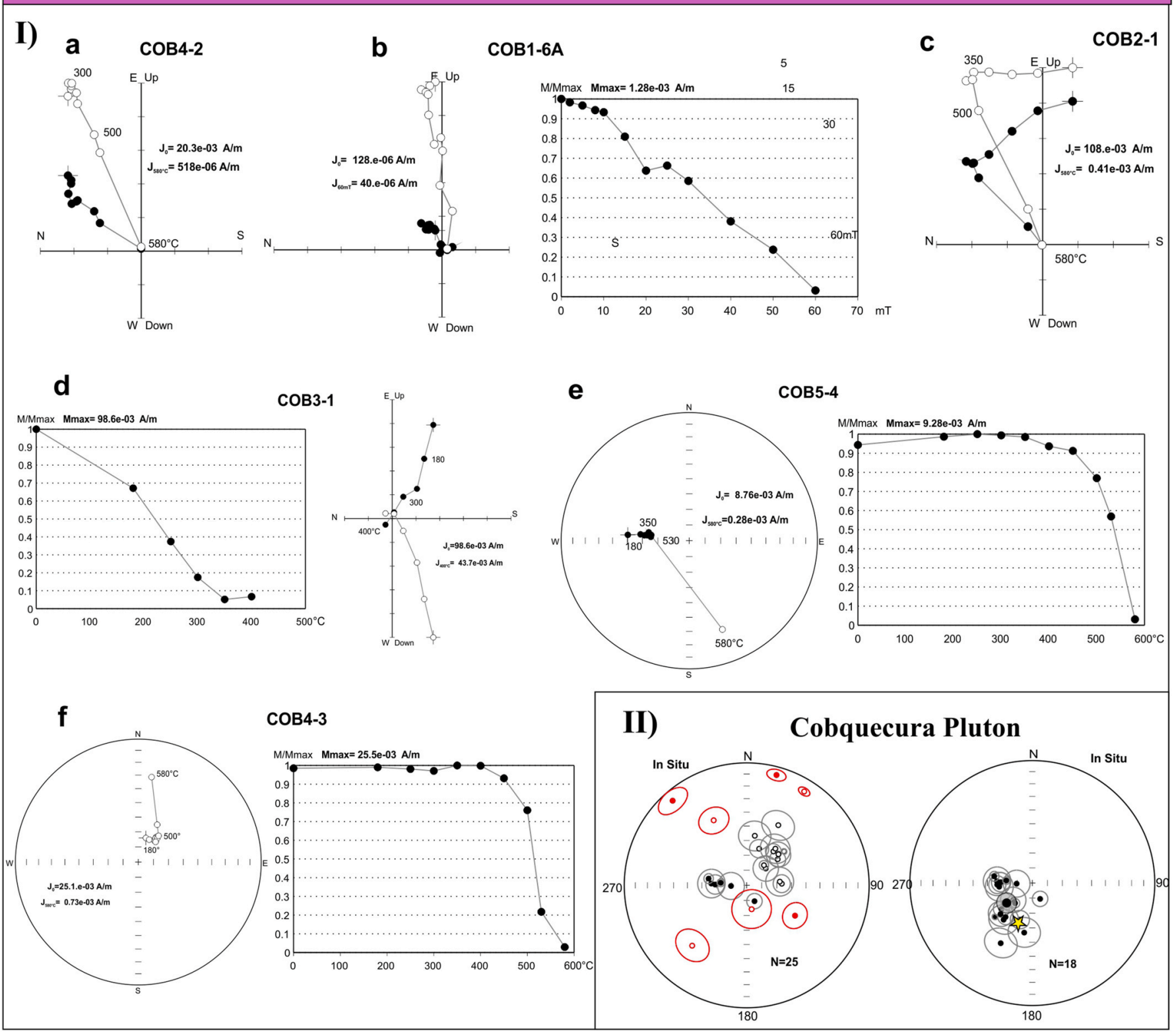

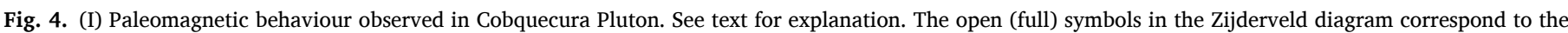

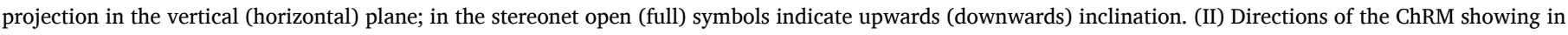

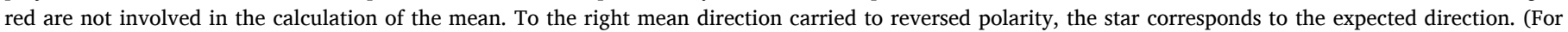
interpretation of the references to color in this figure legend, the reader is referred to the Web version of this article.)

\section{et al., 2005; Astudillo et al., 2009; Arriagada et al., 2013).}

Japas and Re (2012) presented an alternative interpretation in which the Maipo Orocline would have been part of the Bolivian Orocline, later disconnected from northern Chile by a counter-clockwise rotation of the coastal segment between $30^{\circ}$ and $33^{\circ} \mathrm{S}$. These authors attributed this younger counter-clockwise rotation to the subduction of Juan Fernández ridge, so that the collision of the ridge would have almost entirely restored the deflection caused by the hourly rotation of the Bolivian Orocline to an orientation close to the pre-oroclinal.

The paleomagnetic rotations obtained in this work for the Constitución Granite and Cobquecura Pluton are similar to data reported by Arriagada et al. (2013) for a $10 \mathrm{Ma}$ intrusive rocks suggesting that all the area rotated as a single block during the Miocene (Fig. 6). Results obtained by Astudillo et al. (2009)) show that no rotations occurred since $5 \mathrm{Ma}$. The large tectonic rotation observed in Cobquecura Pluton exceeds the expected tectonic rotation due to horizontal shortening. This rotation can be explained as a consequence of a transfer zone to accommodate the change in style and distribution of deformation between Cobquecura Pluton and counter-clockwise to insignificant tectonic rotation obtained from Hualpén Stock. In that case, the Maipo and Arauco Oroclines limit is located to the north of the stock. However, more paleomagnetic and structural data is needed in order to corroborate this hypothesis.

\section{Conclusion}

Paleomagnetic data obtained from the Upper Triassic Constitución Granite and Cobquecura Pluton indicate an increase of clockwise tectonic rotations from north to south. The similar amounts of tectonic rotations recorded by Mesozoic and Miocene rocks suggest that no 


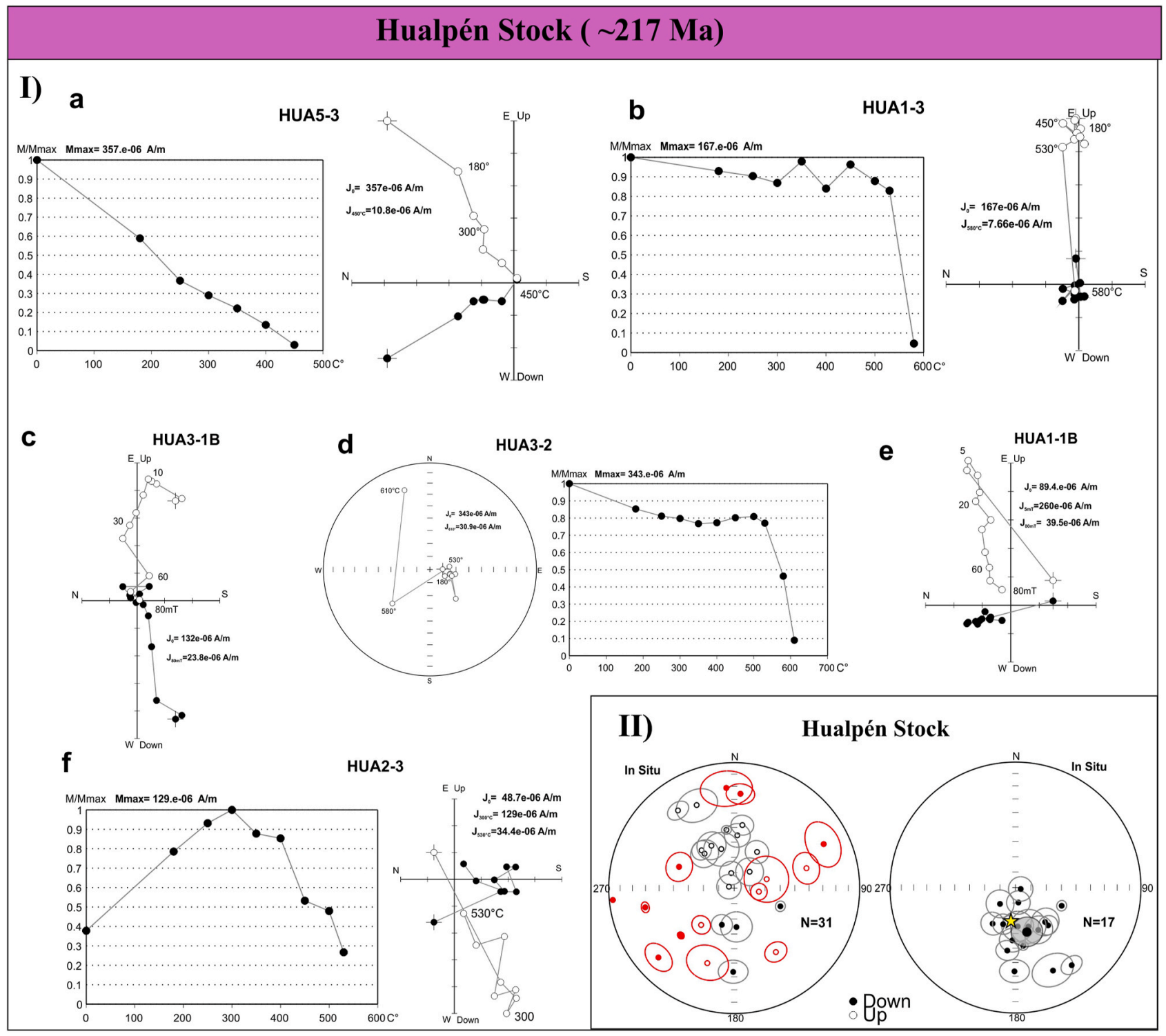

Fig. 5. (I) Paleomagnetic behavior observed in Hualpén Stock. (a-e) AF or thermal demagnetization plots for representative samples with a unique component. (f) Sample showing two components. See Fig.1 for references. (II) Directions of the ChRM showing in red the direction discarded in the calculation of the mean (left). To the right mean direction transposed to reverse polarity, the star corresponds to the expected direction. (For interpretation of the references to color in this figure legend, the reader is referred to the Web version of this article.)

Table 4

Tectonic rotations.

\begin{tabular}{|c|c|c|c|c|c|c|c|c|c|c|c|}
\hline Locality & Lat. & Long & age ref. & Dec.obs. & Inc.obs & $\alpha 95$ & Dec.exp & Inc.exp & $\alpha 95$ & $\mathrm{R} \pm \Delta \mathrm{R}$ & $\mathrm{I} \pm \Delta \mathrm{I}$ \\
\hline Constitución Granite & -35.3 & -72.4 & 220 & 15.4 & -58.2 & 7.2 & 1.9 & -68.1 & 1.5 & $13.5 \pm 11.5$ & $9.9 \pm 5.8$ \\
\hline Cobquecura Pluton & -36.1 & -72.8 & 210 & 232.1 & 68.4 & 6.7 & 190.8 & 66 & 1.5 & $41.3 \pm 15$ & $-2.4 \pm 5.5$ \\
\hline Hualpén Stock & -36.7 & -73.2 & 220 & 165.6 & 60 & 9.9 & 181.6 & 68.1 & 1.5 & $-16.0 \pm 16.4$ & $9.1 \pm 8.0$ \\
\hline
\end{tabular}

Age: estimated age of the magnetization and of the reference from Torsvik et al. (2012) used to calculate the rotation; Lat, Long: Latitude, longitude, position of the locali-ties used in the calculation of the tectonic parameters; Dobs, Iobs: observed paleomagnetic declination and inclination; a95: semi-angle of confidence; Dexp, Iexp: are the expected declination and inclination from expected pole; $\mathrm{R}\left({ }^{\circ}\right), \Delta \mathrm{R}, \mathrm{I}\left({ }^{\circ}\right), \Delta \mathrm{I}$ : rotation and inclination and their associated errors (Demarest Harold, 1983).

rotations occurred in the area during the Gondwana breakup. Considering the good correspondence between the balanced section analyses with the paleomagnetic data, we believe that the deflection in the trench heading and the tectonic rotations of this segment respond to differential shortening north of $36^{\circ} \mathrm{S}$. In contrast, the Hualpén granite $(-217 \mathrm{Ma})$ registers minor to insignificant counter-clockwise rotations for the southern area. This change from north to south suggests that the boundary between the Maipo and Arauco oroclines is located to the north of the Hualpén granite.

\section{Author statement}

All persons who meet authorship criteria are listed as authors, and all authors certify that they have participated sufficiently in the work to take public responsibility for the content, including participation in the concept, design, analysis, writing, or revision of the manuscript. 

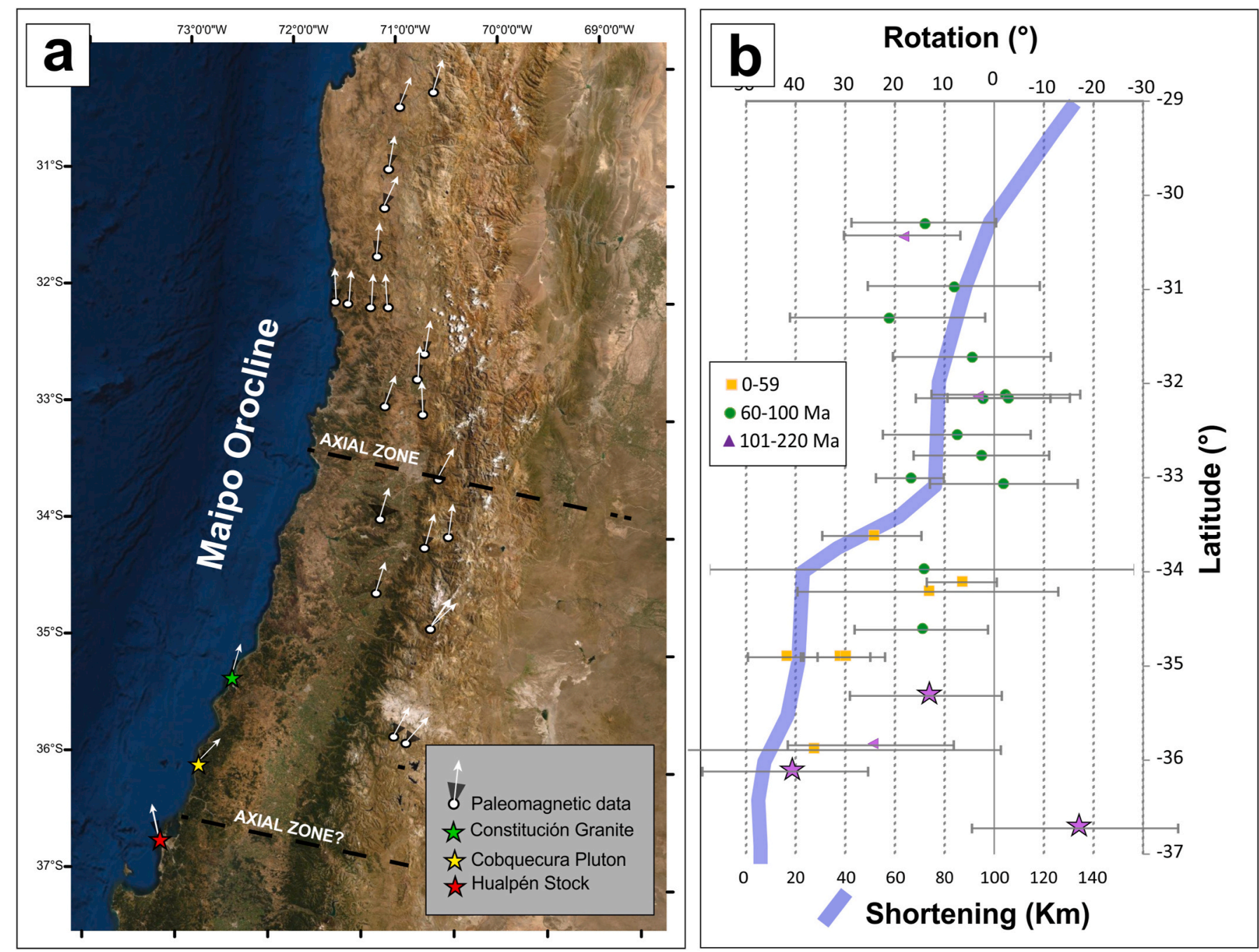

Fig. 6. (a) Compilation of tectonic rotations (deviation of arrows from a NS direction) with errors between $30^{\circ}$ and $37^{\circ} \mathrm{S}$. (b) Paleomagnetic rotation colored by ages of magnetization plotted against latitude. Blue line corresponded to a maximum horizontal shortening according to Allmendinger et al. (1990); Von Gosen (1992); Ramos et al. (1996, 2002); Giambiagi et al. (2012); Allmendinger and Judge (2014); Rojas Vera et al. (2014). Stars correspond to this study. (For interpretation of the references to color in this figure legend, the reader is referred to the Web version of this article.)

\section{Declaration of competing interest}

The authors declare that they have no known competing financial interests or personal relationships that could have appeared to influence the work reported in this paper.

\section{Acknowledgment}

This study was funded through the FONDECYT Iniciación grant 11160329 (Pablo Rossel) and the regular UNAB proyect DI-1278-16/R (Pablo Rossel). F. Carvajal is thanked for assistance in field work. Super IAPD software packages by Torsvik (NGU) and Remasoft program (AGICO SA) were used to analyse the data. Thanks to the two anonymous referees for provided careful and constructive reviews to our manuscript.

\section{References}

Aguirre, L., Hervé, F., Godoy, E., 1972. Distribution of metamorphic facies in Chile, an outline. Kristalinikum 9, 7-19.

Allmendinger, R.W., Figueroa, D., Snyder, D., et al., 1990. Foreland shortening and crustal balancing in the Andes at $30^{\circ} \mathrm{S}$ latitude. Tectonics 4, 789-809.
Allmendinger, R.W., Judge, P.A., 2014. The argentine precordillera: a foreland thrust belt proximal to the subducted plate. Geosphere 10, 1203-1218. https://doi.org/ 10.1130/GES01062.1.

Arriagada, C., Ferrando, R., Córdova, L., et al., 2013. El Oroclino del Maipo: un rasgo estructural de primer orden en la evolución geodinámica Mioceno a Reciente en los Andes de Chile central. Andean Geol. 40, 419-437. https://doi.org/10.5027/ andgeoV40n3-a02.

Arriagada, C., Mpodozis, C., Yañez, G., et al., 2009. Rotaciones tectónicas en Chile central : el oroclino de Vallenar y el "megakink" del Maipo. XII Congreso Geologico Chileno. Santiago de Chile, pp. 1-4.

Astudillo, N., Roperch, P., Townley, B., et al., 2009. Magnetic polarity zonation within the El Teniente copper-molybdenum porphyry deposit, central Chile. Miner. Deposits 45, 23-41. https://doi.org/10.1007/s00126-009-0256-0.

Bahlburg, H., Hervé, F., 1997. Geodynamic evolution and tectonostratigraphic terranes of northwestern Geodynamic evolution and tectonostratigraphic terranes of northwestern Argentina and northern Chile. Geol. Soc. Am. Bull. 109, 869-884. https://doi.org/10.1130/0016-7606(1997)109<0869.

Beck, M.E., Burmester, R.F., Garcia, A., Rivano, S., 1990. Paleomagnetic results from cretaceous rocks in the llaiillay-san felipe-putaendo region: implications for block rotations in the andean forearc. Rev. Geol. Chile 17, 115-130.

Beck, M.E., Drake, R.E., Butler, R.F., 1986. Paleomagnetism of Cretaceous volcanic rocks from central Chile and implications for the tectonics of the Andes. Geology 14 132-136 doi: 10.1130/0091-7613(1986)14<132:POCVRF>2.0.CO;2.

Beck, M.E., Garcia, R.A., Burmester, R.F., et al., 1991. Paleomagnetism and geochronology of late Paleozoic granitic rocks from the Lake District of southern Chile: implications for accretionary tectonics. Geology 19, 332-335 doi: 10.1130 0091-7613(1991)019<0332:PAGOLP>2.3.CO;2.

Berg, K., Breitkreuz, C., 1983. Mesozoische Plutone in der Nordchilenischen Kustenkordillere: petrouenese. Geochronologie, Geochemie und Geodynamik mantelbetonter magmatique. Geotekt. Forsch. 66, 107. 
Berg, K., Breitkreuz, C., Damm, K.W., et al., 1983. The North-Chilean Coast Range - an example for the development of an active continental margin. Geol. Rundsch. 72, 715-731. https://doi.org/10.1007/BF01822090.

Carey, S.W., 1955. The orocline concept in geotectonics-Part I. Pap. Proc. R. Soc. Tasman. 89, 255-288.

Charrier, R., 1979. El Triásico en Chile y regiones adyacentes de Argentina: una reconstrucción paleogeográfica y paleoclimática. Communicaciones 26, 1-37.

Charrier, R., Farías, M., Maksaev, V., 2009. Evolución tectónica, paleogeográfica y metalogénica durante el cenozoico en los Andes de Chile Norte y Central e implicaciones para las regiones adyacentes de Bolivia y Argentina. Rev. la Asoc. Geol. Argentina 65, 5-35.

Charrier, R., Wyss, A.R., Flynn, J.J., et al., 1996. New evidence for late mesozoic-early cenozoic evolution of the Chilean Andes in the upper tinguiririca valley $\left(35^{\circ} \mathrm{s}\right)$, central Chile. J. South Am. Earth Sci. 9, 393-422. https://doi.org/10.1016/s08959811(96)00035-1.

Coira, B., Davidson, J., Mpodozis, C., Ramos, V., 1982. Tectonic and magmatic evolution of the Andes of northern Argentina and Chile. Earth Sci. Rev. 18, 303-332. https:// doi.org/10.1016/0012-8252(82)90042-3.

Creixell, C., Lucassen, F., Franz, G., et al., 2002. Petrology of Hualpen stock : evidences of Late Triassic crustal epizonal plutonism at the Western margin of Gondwana ( $36^{\circ} 45$ ' S - 73'10' W ). V ISAG. Toulouse-France, pp. 167-170.

Creixell, C., Parada, M.Á., Roperch, P., et al., 2006. Syntectonic emplacement of the middle jurassic concón mafic dike swarm, coastal range, central Chile $\left(33^{\circ} \mathrm{S}\right)$. Tectonophysics 425, 101-122. https://doi.org/10.1016/j.tecto.2006.07.005.

Dashwood, B., Taylor, G.K., 2005. Temporal and spatial constraints on multi-phase crustal rotaltion in the forearc of northern Chile. 6th Int Symp Andean Geodyn (ISAG 2005, Barcelona), Ext Abstr 202-205 202-205.

Deenen, M.H.L., Langereis, C.G., van Hinsbergen, D.J.J., Biggin, A.J., 2011. Geomagnetic secular variation and the statistics of palaeomagnetic directions. Geophys. J. Int. 186, 509-520. https://doi.org/10.1111/j.1365-246X.2011.05050.x.

Demarest Harold, H., 1983. Error Analysis for the Determination of tectonic rotation from paleomagnetic data. J. Geophys. Res. 88, 4321-4328.

Dewey, J.F., Lamb, S.H., 1992. Active tectonics of the Andes. Tectonophysics 205, 79-95. https://doi.org/10.1016/0040-1951(92)90419-7.

Farías, M., Charrier, R., Carretier, S., et al., 2008. Late Miocene high and rapid surface uplift and its erosional response in the Andes of central Chile $\left(33^{\circ}-35^{\circ} \mathrm{S}\right)$. Tectonics 27. https://doi.org/10.1029/2006TC002046.

Ferrando, R., Roperch, P., Morata, D., et al., 2014. A paleomagnetic and magnetic fabric study of the Illapel Plutonic Complex, Coastal Range, central Chile: implications for emplacement mechanism and regional tectonic evolution during the midCretaceous. J. South Am. Earth Sci. 50, 12-26. https://doi.org/10.1016/J JSAMES.2013.11.007.

Fisher, R.A., 1953. Dispersion on a sphere. Proc. R. Soc. London Ser. A 217, 295-305.

Gana, P., Hervé, F., 1983. Geología del basamento cristalino en la Cordillera de la Costa entre los ríos Mataquito y Maule, VII Región. Rev. Geol. Chile Int. J. Andean Geol. 37-56. https://doi.org/10.5027/ANDGEOV10N2-3-A03.

Giambiagi, L., Mescua, J., Bechis, F., et al., 2012. Thrust belts of the southern Central Andes: along-strike variations in shortening, topography, crustal geometry, and denudation. Bull. Geol. Soc. Am. 124, 1339-1351. https://doi.org/10.1130/ B30609.1.

Glodny, J., Echtler, H., Figueroa, O., et al., 2006. Long-term geological evolution and mass-flow balance of the south-central Andes. In: The Andes. Springer Berlin Heidelberg, pp. 401-428.

Glodny, J., Lohrmann, J., Echtler, H., et al., 2005. Internal dynamics of a paleoaccretionary wedge: insights from combined isotope tectonochronology and sandbox modelling of the South-Central Chilean forearc. Earth Planet Sci. Lett. 231, 23-39. https://doi.org/10.1016/j.epsl.2004.12.014.

Goguitchaichvili, A., Chauvin, A., Roperch, P., et al., 2000. Palaeomagnetism of the Miocene farellones formation (Chile). Geophys. J. Int. 140, 357-373. https://doi. $\operatorname{org} / 10.1046 / j .1365-246 x .2000 .00022 . x$.

Hervé, F., Munizaga, F., Parada, M.A., et al., 1988. Granitoids of the coast range of central Chile: geochronology and geologic setting. J. South Am. Earth Sci. 1 , 185-194. https://doi.org/10.1016/0895-9811(88)90036-3.

Isacks, B.L., 1988. Uplift of the central andean plateau and bending of the Bolivian orocline. J. Geophys. Res. 93, 3211-3231. https://doi.org/10.1029/ JB093iB04p03211.

Japas, M.S., Re, G.H., 2012. Neogene tectonic block rotations and margin curvature at the pampean flat slab segment ( $28^{\circ}-33^{\circ} \mathrm{sl}$, Argentina ). Geoacta 37, 1-4.

Kirschvink, J.L., 1980. The least-squares line and plane and the analysis of palaeomagnetic data. Geophys. J. Int. 62, 699-718. https://doi.org/10.1111/j.1365246X.1980.tb02601.x.

Lucassen, F., Trumbull, R., Franz, G., et al., 2004. Distinguishing crustal recycling and juvenile additions at active continental margins: the Paleozoic to recent compositional evolution of the Chilean Pacific margin (36-41 ${ }^{\circ}$ S). J. South Am. Earth Sci. 17, 103-119. https://doi.org/10.1016/j.jsames.2004.04.002.

Martin, M.W., Kato, T.T., Rodriguez, C., et al., 1999. Evolution of the late Paleozoic accretionary complex and overlying forearc-magmatic arc, south central Chile ( $38^{\circ}$ - $41^{\circ} \mathrm{S}$ ): constraints for the tectonic setting along the southwestern margin of Gondwana. Tectonics 18, 582-605. https://doi.org/10.1029/1999TC900021.

McFadden, P.L., McElhinny, M.W., 1990. Classification of the reversal test in palaeomagnetism. Geophys. J. Int. 103, 725-729. https://doi.org/10.1111/j.1365246X.1990.tb05683.x.

Melnick, D., Bookhagen, B., Strecker, M.R., Echtler, H.P., 2009. Segmentation of megathrust rupture zones from fore-arc deformation patterns over hundreds to millions of years, Arauco peninsula, Chile. J. Geophys. Res. 114, 1407. https://doi. org/10.1029/2008JB005788.

Mpodozis, C., Kay, S., 1990. Provincias magmaticas acidas y evolucion tectonica de Gondwana : Andes Chilenos (28-31 ${ }^{\circ}$ S). Rev. Geol. Chile 17, 153-180. https://doi. org/10.5027/andgeoV17n2-a03.

Mpodozis, C., Ramos, V.A., 1989. The Andes of Chile and Argentina. In: Geology of the Andes and its Relation to Hydrocarbon and Mineral Resources, vol. 11, pp. 59-90.

Parada, M.A., Féraud, G., Fuentes, F., et al., 2005. Ages and cooling history of the Early Cretaceous Caleu pluton: testimony of a switch from a rifted to a compressional continental margin in central Chile. J. Geol. Soc. Londn. 162, 273-287. https://doi. org/10.1144/0016-764903-173.

Peña, M., Arriagada, C., Martinez, F., Creixell, C., 2011. Oroclino de Vallenar : un estudio geológico y paleomagnético. In: Latinmag Letters, pp. 1-6. Tandil-Argentina.

Ramos, V.A., Cegarra, M., Cristallini, E., 1996. Cenozoic tectonics of the High Andes of west-central Argentina (30-36 ${ }^{\circ}$ latitude). Tectonophysics 259, 185-200. https:// doi.org/10.1016/0040-1951(95)00064-X.

Ramos, V.A., Cristallini, E.O., Pérez, D.J., 2002. The pampean flat-slab of the central Andes. J. South Am. Earth Sci. 15, 59-78. https://doi.org/10.1016/S0895-9811(02) 00006-8.

Rehak, K., Strecker, M.R., Echtler, H.P., 2008. Morphotectonic segmentation of an active forearc, $37^{\circ}-41^{\circ} \mathrm{S}$, Chile. Geomorphology 94, 98-116. https://doi.org/10.1016/j. geomorph.2007.05.002.

Richter, P.P., Ring, U., Willner, A.P., Leiss, B., 2007. Structural contacts in subduction complexes and their tectonic significance: the Late Palaeozoic coastal accretionary wedge of central Chile. J. Geol. Soc. Londn. 164, 203-214. https://doi.org/10.1144/ 0016-76492005-181.

Rojas Vera, E.A., Folguera, A., Zamora Valcarce, G., et al., 2014. Structure and development of the Andean system between $36^{\circ}$ and $39^{\circ}$ S. J. Geodyn. 73, 34-52. https://doi.org/10.1016/j.jog.2013.09.001.

Ruiz González, V., Puigdomenech, C.G., Zaffarana, C.B., et al., 2020. Paleomagnetic evidence of the brittle deformation of the central patagonian batholith at gastre area (chubut province, Argentina). J. South Am. Earth Sci. 98, 102442. https://doi.org/ 10.1016/j.jsames.2019.102442.

Suarez, M., Bell, C.M., 1992. Triassic rift-related sedimentary basins in northern Chile $\left(24^{\circ}\right.$-29 $^{\circ}$ S). J. South Am. Earth Sci. 6, 109-121. https://doi.org/10.1016/0895-9811 (92)90001-F.

Torsvik, T.H., Van der Voo, R., Preeden, U., et al., 2012. Phanerozoic polar wander, palaeogeography and dynamics. Earth Sci. Rev. 114, 325-368. https://doi.org/ 10.1016/j.earscirev.2012.06.007.

Uliana, M.A., Biddle, K.T., 1988. Mesozoic-cenozoic paleogeographic and geodynamic evolution of southern south America. Rev. Bras. Geociencias 18, 172-190. https:// doi.org/10.25249/0375-7536.1988182172190.

Vásquez, P., Franz, G., 2008. The Triassic Cobquecura Pluton (Central Chile): an example of a fayalite-bearing A-type intrusive massif at a continental margin. Tectonophysics 459, 66-84. https://doi.org/10.1016/j.tecto.2007.11.067.

Vásquez, P., Franz, G., Wemmer, K., 2005. Fe-rich silicates in the Cobquecura pluton: an indicator ofA-type granitoids in the Triassic magmatism of south-central Chile. In: 6th International Symposium on Andean Geodynamics. Barcelona, Spain, pp. 773-775.

Vásquez, P., Glodny, J., Franz, G., et al., 2009. Origin of fayalite granitoids: new insights from the Cobquecura Pluton, Chile, and its metapelitic xenoliths. Lithos 110, 181-198. https://doi.org/10.1016/j.lithos.2009.01.001.

Vásquez, P., Glodny, J., Franz, G., et al., 2011. Early mesozoic plutonism of the Cordillera de la Costa $\left(34^{\circ}-37^{\circ} \mathrm{s}\right)$, Chile: constraints on the onset of the andean Orogeny. J. Geol. 119, 159-184. https://doi.org/10.1086/658296.

Von Gosen, W., 1992. Structural evolution of the Argentine precordillera: the río san juan section. J. Struct. Geol. 14, 643-667. https://doi.org/10.1017/ CBO9781107415324.004.

Willner, A.P., Thomson, S.N., Kröner, A., et al., 2005. Time markers for the evolution and exhumation history of a Late Palaeozoic paired metamorphic belt in North-Central Chile (34ํ- $35^{\circ} 30^{\prime}$ S). J. Petrol. 46, 1835-1858. https://doi.org/10.1093/petrology/ egi036.

Wilson, R.L., Dagley, P., McCormack, A.G., et al., 1972. Palaeomagnetic evidence about the source of the geomagnetic field. Geophys. J. Roy. Astron. Soc. 28, 213-224, 1972.

Yáñez, G., Cembrano, J., Pardo, M., et al., 2002. The Challenger-Juan Fernández-Maipo major tectonic transition of the Nazca-Andean subduction system at $33-34^{\circ} \mathrm{S}$ : geodynamic evidence and implications. J. South Am. Earth Sci. 15, 23-38. https:// doi.org/10.1111/jace.13350. 